\title{
Diversitas persepsi masyarakat terhadap pendidikan
}

\author{
Fajar Wahyudi Utomo ${ }^{\text {a, }}{ }^{*}$, Risma Sugihartati ${ }^{\text {b, } 2}$ \\ ${ }^{a, b}$ Universitas Indraprasta PGRI, Jakarta, Indonesia \\ ${ }^{I}$ adan29.wahyudi@gmail.com*; risma.sugihartati@gmail.com
}

\begin{tabular}{ll}
\hline Informasi artikel & ABSTRAK \\
\hline Kata kunci: & Persepsi masyarakat tentang sesuatu hal dapat berbeda berdasarkan pengalaman baik yang \\
Persepsi, & dialami secara pribadi maupun kolektif. Dalam penelitian ini fokus utama adalah melihat \\
Pendidikan & dan mendeskripsikan secara mendalam, beragam persepsi yang ada khususnya pada \\
& masyarakat gang Mundu. Jarak yang tidak seberapa jauh dengan Kampus Gedong \\
& UNINDRA dapat menghasilkan beragam persepsi masyarakat mengenai pendidikan. \\
& Persepsi tidak hanya sekadar berbentuk opini, melainkan dapat terwujud dalam suatu \\
& aktivitas yang didorong oleh suatu keinginan yang ada dalam diri manusia. Penelitian ini \\
& menggunakan metode kualitatif dengan pendekatan deskriptif. Pengumpulan data \\
& dilakukan dengan mengamati dan mewawancarai sampel representatif yakni warga \\
& masyarakat Gang Mundu. Penelitian ini berusaha mengungkap serta menggambarkan \\
& berbagai macam persepsi yang dimiliki masyarakat Gang mundu dengan harapan dapat \\
& bermanfaat sebagai bahan refleksi. Hasil riset di lapangan menemukan terdapat berbagai \\
& keberagaman persepsi yang dimiliki oleh masyarakat Gang Mundu. Persepsi tersebut \\
& terbagi menjadi beberapa pola. Pola - pola tersebut antara lain, pola sosial, pola ekonomi \\
& dan pola akademik. Berbagai macam pola ini tentunya tercipta sebagai hasil hubungan \\
& timbal balik antara masyarakat Gang Mundu dengan hadirnya Kampus Gedong \\
& UNINDRA. Lebih jauh, hubungan timbal balik yang terjadi bukan sekadar persepsi yang \\
& tercipta dari hasil tangkapan indera saja melainkan hasil dari interaksi yang sulit dari \\
& kegiatan seleksi, penyusunan dan penafsiran.
\end{tabular}

Keywords:

Diversity,

Perception,

Education

\begin{abstract}
Public perceptions about things which can be different based on both, personal and collective experiences. In this study the main focus is to see and describe deeply, a variety of perceptions which exists especially in the community of Mundu lane. The distance which is not too be far with Campus gedong, UNINDRA, can produce various perceptions of society about education. According to Lave (1996) perception is not only manifested into human beings, but also manifested by human practices or actions. Therefore, it is not merely an experience, but also it can be realized in an activity that is encouraged by a desire that exists in a human being. This research uses a qualitative method and descriptive approach. The data were collected by observing and interviewing the representative sample which is the community of Mundu lane. This research tries to reveal and review various kinds of perception owned by society in mundu lane, with the aim, it can be useful as a reflection material of campus. The results of the research in the field found various diversity of perception owned by mundu lane society. The perception is divided into several patterns. These patterns include social patterns, economic patterns and academic patterns. Various patterns of this course created as a result of mutual relations between the Mundu lane community with the presence of Campus gedong UNINDRA. Furthermore, reciprocal relationships are not merely the perceptions created by the sensual catch but also the result from the difficult conflicts of selection, compilation and interpretation
\end{abstract}

Copyright (C) 2018 Fajar Wahyudi Utomo dan Risma Sugihartati . All Right Reserved

\section{PENDAHULUAN}

Dilihat dari perspektif sejarah, hadirnya pendidikan di Indonesia tidak terlepas dari Bangsa Belanda yang menerapkan sistem politik balas budi. Pendirian sekolah-sekolah di Indonesia ditujukan untuk mencerdaskan bangsa Indonesia agar kelak menjadi tenaga-tenaga 
terdidik dan mampu dimanfaatkan oleh Bangsa Belanda. Namun pendidikan ternyata mengubah segalanya. Pendidikan mengubah pola pemikiran bangsa Indonesia untuk lepas dari penjajahan Bangsa Belanda dan menjadi bangsa yang merdeka.

Pendidikan memang fondasi dasar sebuah Bangsa. Melalui pendidikan suatu Bangsa dapat mengubah peradabannya. Oleh karena itu sudah sewajarnyalah, pengupayaan yang maksimal dan apresiasi yang setinggi-tingginya harus ditujukan kepada semua pihak yang berkaitan dengan pendidikan. Hadirnya pendidikan di masyarakat menimbulkan berbagai macam persepsi dan sudut pandang. Persepsi tersebut menuai berbagai keragaman. Bagi sebagian masyarakat yang sadar akan pentingnya sebuah pendidikan, maka mereka akan memperjuangkan dan mengapresiasi pendidikan agar tetap ada dan mempertahankan mutu serta kualitasnya. Akan tetapi bagi sebagian masyarakat lain, pendidikan juga dianggap merusak corak orisinalitas suatu budaya. Karena bagi mereka pendidikan dapat mengubah tatanan tradisional yang kemudian terbawa arus globalisasi.

Dalam persepsi lain hadirnya pendidikan di tengah-tengah masyarakat juga mampu memberikan berbagai macam nilai manfaat. Manfaat tersebut antara lain mengubah cara berpikir irasional menjadi rasional. Mencerdaskan kehidupan masyarakat agar menjadi bangsa yang lebih maju. Selain itu, hadirnya pendidikan juga mampu mengangkat nilai status sosial seseorang. Individu atau keluarga yang awalnya hanya berasal dari status sosial ekonomi rendah berubah menjadi status sosial ekonomi yang lebih tinggi. Hal ini disebabkan seseorang yang telah menempuh pendidikan dapat menguasai bidang ilmu tertentu.

Hal lain yang bersifat laten atau tersembunyi dari hadirnya pendidikan di tengah-tengah masyarakat ialah ternyata berdirinya suatu lembaga pendidikan di tengah masyarakat mampu membawa perubahan dalam nilai ekonomi. Hal ini yang juga yang terjadi pada masyarakat Gang Mundu, Kampung Tengah dengan hadirnya Kampus B Universitas Indraprasta PGRI di tengah pemukiman mereka. Semenjak berdirinya UNINDRA di tengah masyarakat Gang Mundu sebagian masyarakat memersepsikannya dari berbagai macam sudut pandang. Keberagaman atau diversitas persepsi inilah yang menjadi daya tarik peneliti untuk meneliti lebih lanjut tentang persepsi masyarakat dengan hadirnya institusi pendidikan di tengah-tengah masyarakat. Khususnya warga masyarakat Gang Mundu, Kelurahan Tengah.

Dalam kamus besar bahasa Indonesia (KBBI) diversitas diartikan perbedaan, kelainan dan keragaman. Dalam istilah ilmu sosial keragaman diartikan sebagai suatu kondisi dalam masyarakat dimana terdapat 
perbedaan-perbedaan dalam berbagai bidang terutama suku bangsa, ras, agama, ideologi, dan budaya. Keragaman dalam masyarakat adalah sebuah keadaan yang menunjukkan perbedaan yang cukup banyak macam atau jenisnya dalam masyarakat. Dalam kamus besar bahasa Indonesia, keragaman berasal dari kata ragam yang berarti, sikap, tingkah laku, cara, macam, jenis, corak, warna, serta corak. Dalam istilah itu sosial keberagaman diterjemahkan dalam beberapa konsep. Konsep - konsep tersebut antara lain diferensiasi sosial serta masyarakat multikultur. diferensiasi sosial merupakan variasi pekerjaan, prestise, serta kekuasaan kelomnpok dalam masyarakat yang dikaitkan dengan interaksi atau akibat umum dari proses interaksi sosial yang lain (Soekanto, 1977).

Menurut para ahli diversifikasi adalah kegiatan atau tindakan untuk membuat sesuatu jadi lebih beragam atau tidak terpaku hanya pada satu jenis saja. Di dalam dunia bisnis, diversifikasi seringkali di identikkan dengan ungkapan "tidak menaruh telur di dalam satu keranjang”. Contoh diversifikasi produk. Diversifikasi produk adalah penganekaragaman bentuk berbagai barang atau jasa tertentu yang akan diedarkan atau diperjualbelikan di pasaran. Dalam ilmu antropologi kata diversifikasi lebih dikenal dengan sebutan keanekaragaman untuk Kebudayaan. Lebih lanjut istilah yang populer digunakan adalah Multikulturalisme. Suparlan (2003)) dalam hal ini melihat multikulturalisme sebagai sebuah ideologi yang mengagungkan perbedaan budaya, atau sebuah keyakinan yang mengakui dan mendorong terwujudnya pluralisme budaya sebagai suatu corak kehidupan masyarakat. Multikulturalisme mengagungkan dan berusaha melindungi keanekaragaman budaya, termasuk kebudayaan dari mereka yang tergolong sebagai minoritas. Model multikulturalisme menekankan pengakuan kesederajatan atas perbedaan-perbedaan yang ada.

Persepsi merupakan proses yang menyangkut masuknya suatu informasi kedalam pikiran seseorang. Melalui persepsi, manusia akan terus menerus mengadakan hubungan dengan lingkungannya. Hubungan manusia itu dilakukan melalui indera penglihatan, pendengaran dan penciuman. Persepsi disebutkan oleh Mar'at (1999, hal. 11) sebagai suatu proses pengamatan seseorang yang berasal dari kemampuan kognitif, menyangkut sesuatu yang dipikirkan mengenai obyek pengamatan. Persepsi merupakan apa yang dialami dengan segera oleh seseorang. Persepsi menghubungkan jalan ke alam sekitar untuk mengetahui, mendengar, mencium, merasa juga membau dengan segera berdasarkan alat indera. Dengan demikian seseorang akan mempunyai persepsi yang beraneka ragam terhadap suatu obyek. Hal ini dapat 
dipahami, mengingat stimulus yang sama sekalipun dapat mengakibatkan penglihatan yang berbeda terhadap suatu obyek, tergantung dari konteks mana stimulus itu dipandang dan tergantung pula pada aspek pengalaman subyek yang memandang. Lebih lanjut mengenai Persepsi, Lave (2009) mengemukakan bahwa "pengetahuan, nilai-nilai, norma-norma, persepsi dan lain-lain tidak hanya terwujud ke dalam diri manusia, tetapi juga diwujudkan oleh praktik-praktik atau tindakan-tindakan manusia”. Baik persepsi maupun pengetahuan merupakan sebuah proses yang dialami oleh manusia. Proses yang berisikan seperangkat aturan untuk bertindak, dan individu dilihat sebagai pelaku yang melakukan encoding dan decoding simbol-simbol, dan mengikuti sebuah grammar.

\section{METODE PENELITIAN}

Metode penelitian yang digunakan dalam penelitian ini adalah metode deskriptif kualitatif. Penelitian yang bersifat deskriptif bertujuan menggambarkan secara tepat sifat individu, keadaan, gejala atau kelompok tertentu dalam masyarakat. Gejala yang dimaksud adalah diversitas atau keberagaman persepsi warga masyarakat Gang Mundu terhadap kehadiran kampus Gedong UNINDRA. Penulis juga memilih "One shot model". Menurut Arikunto (2013)“One shot model yaitu model pendekatan yang menggunakan satu kali pengumpulan data pada suatu saat". Jadi, penulis melakukan penelitian ini dengan hanya menggunakan waktu 1 hari untuk penelitian langsung ke lokasi penelitian dan melakukan pengumpulan data penelitian dari warga masyarakat Gang Mundu. Data tersebut diidentifikasi, diklasifikasikan, dan dianalisis, kemudian dideskripsikan dalam sebuah laporan penelitian yang dapat digunakan sebagai bahan kajian dan keilmuan tentang persepsi masyarakat terhadap pendidikan, khususnya masyarakat Gang Mundu terhadap Kampus Gedong UNINDRA.

\section{HASIL DAN PEMBAHASAN}

Teori tentang persepsi sosial banyak dikemukakan oleh para pakar pengetahuan. Salah satu pemaparan pengertian tentang persepsi sosial dijelaskan oleh Walgito (2003:53). Menurutnya persepsi sosial merupakan suatu proses yang didahului oleh pengindraan, yaitu merupakan proses yang berwujud diterimanya stimulus oleh individu melalui alat reseptornya. Proses ini diteruskan ke pusat susunan saraf atau otak dan terjadilah proses psikologi, sehingga individu menyadari apa yang mereka lihat, apa yang Ia dengar dan sebagiannya.

Secara singkat pendapat David Krech (Duncan dalam Thohah,2002:124) mengatakan bahwa persepsi adalah suatu proses kognitif yang kompleks dan menghasilkan suatu gambar unik tentang kenyataan yang sangat berbeda dari kenyataannya. Persepsi yang signifikan adalah jika diperluas di luar jangkauan lima 
indera dan merupakan unsur penting. Tidak jauh berbeda Luthans (Luthans dalam Thoha, 2002 : 125) menyatakan bahwa proses persepsi meliputi suatu interaksi yang sulit dari kegiatan seleksi, penyusunan dan penafsiran. Walaupun persepsi sangat bergantung pada pengindraan data namun proses kognitif bisa menyaring, menyederhanakan dan mengubah secara sempurna data tersebut. Jadi dari macammacam pendapat yang memberikan terhadap persepsi, dapat diketahui bahwa persepsi adalah sebuah anggapan, penilaian atau pandangan yang datang dari suatu keadaan yang menarik perhatian orang untuk memberikan partisipasi argumen baik secara langsung atau tidak langsung.

Berkaitan dengan beberapa pengertian di atas tentang persepsi sosial. Begitu juga berbagai persepsi masyarakat Gang Mundu terhadap Hadirnya Kampus Gedong, institusi pendidikan baik secara sadar maupun tidak banyak membawa warna perubahan baru bagi masyarakat sekitarnya. Lebih jauh, seperti yang dikemukakan oleh David Krech dan Luthans bahwa persepsi tidak hanya sekedar proses diterimanya stimulus oleh alat indera kemudian diteruskan ke otak. Lebih dari itu persepsi yang signifikan adalah jika diperluas di luar jangkauan lima alat indera dan merupakan unsur penting di dalam penyesuaian perilaku manusia.

Terdapat hubungan timbal balik antara Kampus Gedong UNINDRA dengan masyarakat yang berada di wilayah sekitarnya. Kehadiran Kampus Gedong UNINDRA membawa perubahan tersendiri bagi masyarakat sekitar khususnya masyarakat Gang Mundu. Perubahan tersebut terjadi baik dari segi pertambahan jumlah penduduk dan sebagian warga yang anaknya kuliah di Kampus gedong UNINDRA. Atas dasar citra yang sudah terbangun, kemudian masyarakat memersepsikan Kampus Gedong UNINDRA berdasarkan pengalaman mereka. Pengalaman-pengalaman tersebut tentunya berdampak bagi kehidupan mereka. Persepsi atas dasar tersebut secara umum terbagi menjadi. Persepsi sosial, ekonomi dan akademik.

Persepsi sosial merupakan persepsi yang diutarakan masyarakat terkait keberadaan Kampus Gedong yang ternyata membawa perubahan sosial. Perubahan sosial ini dirasakan dari segi pertambahan jumlah penduduk, kemudian lingkungan pergaulan yang semakin tenang dan nyaman semenjak berdirinya Kampus Gedong UNINDRA. Ketenangan dan rasa kenyamanan ini dirasakan oleh warga akibat sebagian warga yang bermukim di sekitar sebagian besar di dominasi oleh kalangan terpelajar. Hal ini tentu saja membangun suasana akademis bagi warga.

Berikutnya adalah persepsi ekonomi. Persepsi ekonomi muncul sebagai dampak yang dirasakan oleh sebagian besar warga di sekitar Kampus Gedong. Semenjak 
hadirnya Kampus Gedong, sebagian warga mendapat berbagai nilai ekonomis. Nilai ekonomi tersebut dapat terlihat dari banyaknya usaha kost-kostan, muncul berbagai macam pedagang di sekitar Kampus. Serta nilai jual tanah yang semakin meningkat. Hal ini tentunya membawa kabar positif bagi mereka yang dapat mengambil peluang dengan hadirnya Kampus Gedong UNINDRA di tengah pemukiman masyarakat.

Terakhir persepsi akademik. Selain persepsi sosial dan ekonomi, persepsi akademik juga dirasakan oleh masyarakat sekitar Kampus Gedong tak terkecuali masyarakat Gang Mundu. Hal ini dibuktikan oleh salah satu warga yang merasa semakin termotivasi untuk melanjutkan pendidikan meski di usia yang tidak lagi muda. Motivasi ini muncul akibat dorongan keinginan untuk meningkatkan kehidupan yang lebih baik. Dan salah satunya melalui pendidikan. Belum lagi, banyak warga yang juga ingin menyekolahkan anaknya hingga perguruan tinggi meskipun sebagian dari mereka berasal dari kalangan ekonomi menengah ke bawah. Secara tidak langsung keberadaan Kampus Gedong mempengaruhi hal tersebut, karena menurut penuturan masyarakat. Jika anaknya mereka harus kuliah akses kampus terdekatlah yang akan mereka pilih.

\section{SIMPULAN}

Kehadiran Kampus Gedong UNINDRA dirasakan membawa pengaruh yang baik bagi warga sekitar. Oleh karena itu warga masyarakat sekitar khususnya Gang Mundu memersepsikan lembaga ini sebagai hal yang positif. Diversitas atau keberagaman persepsi yang diutarakan oleh warga Gang Mundu secara umum terbagi menjadi 3, Persepsi sosial, persepsi ekonomi dan persepsi akademik. Persepsi sosial ialah persepsi yang berkaitan erat dengan perubahan interaksi dan hubungan sosial yang dirasakan warga semenjak hadirnya kampus Gedong UNINDRA. Sedangkan persepsi ekonomi adalah persepsi yang dirasakan warga sebagai dampak ekonomi positif akibat hadirnya Kampus Gedong UNINDRA. Dan terakhir adalah persepsi akademik. Persepsi yang berkaitan erat dengan motivasi warga yang terdorong untuk menempuh pendidikan lebih tinggi yang secara tidak langsung juga dipengaruhi oleh kehadiran Kampus Gedong UNINDRA.

\section{REFERENSI}

Arikunto, S. (2013). Prosedur penelitian. Suatu pendekatan praktek (15 ed.). Jakarta: Rineka Cipta.

Lave, J. (2009). The practice of learning. In K. Illeris (Ed.), Contemporary Theories of Learning: Learning Theorists -- In Their Own Words. Routledge.

Mar'at. (1999). Sikap manusia perubahan dan pengukurannya. Jakarta: Ghalia Indonesia. 
Soekanto, S. (1977). Hukum dan masyarakat. Surabaya: Universitas Airlangga.

Suparlan, P. (2003). Bhinneka Tunggal Ika: Pendahuluan: masyarakat majemuk Indonesia dan permasalahannya. Antropologi Indonesia, 72, 24-37. 